\title{
超伝導永久磁石の開発に関する現状
}

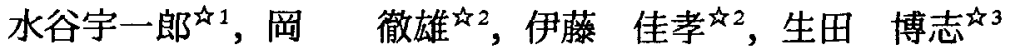 \\ 4 1 名古屋大学大学院工学研究科結晶材料, $\overline{4} 464-8603$ 名古屋市千種区不老町. \\ 中2 (㴊) イムラ材料開発研究所, 广 448-0021 刈谷市八軒町 5-50. \\ 43 名古屋大学理工科学総合研究センター, 个 464-8603 名古屋市千種区不老町.
}

\section{Recent Development in Superconducting Permanent Magnets}

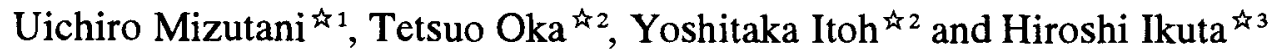 \\ ${ }^{4}$ Dept. of Crystalline Materials Science, Nagoya University, Furo-cho Chikusa-ku, Nagoya 464-8603. \\ ${ }^{2}$ IMRA MATERIAL R\&D CO., LTD., Hachiken-cho, Kariya 448-0021. \\ ${ }^{4}{ }^{3}$ Center for Integrated Research in Science and Engineering, Nagoya University, Furo-cho Chikusa-ku, Nagoya 464-8603.
}

Received August 17, 1999

\section{SYNOPSIS}

The c-axis oriented single-domain $\mathrm{Sm} 123$ bulk superconductors have been synthesized in the melt-texturing process. The maximum trapped flux density has reached $1.7 \mathrm{~T}$ at $77 \mathrm{~K}$ and $9.0 \mathrm{~T}$ at $25 \mathrm{~K}$ at the center of sample surface. Detailed analysis on the flux motion through the pulsed field magnetization (PFM) process revealed that the iteratively magnetizing pulsed field operation with reducing amplitude (IMRA method) is very effective in magnetizing high $J_{c}$ bulk superconductors at temperatures near $30 \mathrm{~K}$, attained by a cryocooler and vacuum pumps. A compact superconducting permanent magnet system driven by the PFM technique has been constructed, which is capable of generating magnetic fields up to $2 \mathrm{~T}$ in the open space outside the magnetic pole.

\section{KEY WORDS}

melt-processing, bulk superconductor, trapped field magnet, pulsed-field magnetization, magnetic field generator

\section{1 緒言}

高温超伝導体は 1986 年にスイスで発見された ${ }^{1)}$. 新たに合 成されたランタン・バリウム・銅の複合酸化物 (La-Ba-Cu-O) は，それまで最高の超伝導遷移温度 $T_{\mathrm{c}}$ をもつニオフ・ゲルマ 二ウム系 (絶対温度 $23 \mathrm{~K}$ ，雲下 $250^{\circ} \mathrm{C}$ ) より高い $30 \mathrm{~K}$ の $T_{\mathrm{c}}$ を示 した. 翌年には液体窒素の沸点 $77 \mathrm{~K}$ (零下 $196^{\circ} \mathrm{C}$ )を超える $90 \mathrm{~K}$ の $T_{\mathrm{c}}$ をもつイットリウム系超伝導体(Y-Ba-Cu-O)が確認され これを契機に活発な開発競争が全世界で始まった。

従来の超伝導体は $T_{\mathrm{c}}$ が低く, 液体へリウム $\left(4 \mathrm{~K}\right.$, 票下 $\left.269^{\circ} \mathrm{C}\right)$ で冷却してはじめて用いることができた．液体へリウムは高 価で資源的にも希少なため，超伝導技術は一般工業に利用さ れることはなく，用途は極めて限定されていた。これに対し 高温超伝導体は $T_{\mathrm{c}}$ 加高く, 安価な液体窒素で泠却できる。 こ のことから，電力をはじめとした広い分野で応用が期待され た. 実際，今日では高温超伝導体を応用した磁気センサや電 流リード(超伝導マグネットに電流を導入する端子)など具体 的な製品が開発され，市場に現れつつある。

これら応用研究のひとつにバルク超伝導体の研究がある゙3.5. Y-Ba-Cu-Oに代表される123系と呼ばれる超伝導体を一旦溶
かして塊状(バルク状)に凝固させた試料は，磁場に反発して 空中に浮上するなど，特幑的な振る舞いをする。特に，磁場 を捕捉することによって得られる「超伝導永久磁石」のと呼ぶ へき性質は，従来の永久磁石はおるか，大型電磁石の磁場を はるかに上回る強力な磁場を発生できることが最近の研究で 明らかになってきた。

従来の永久磁石が発生できる磁場は実質的には1T(テスラ， 1テスラは1万ガウス)以下である. 水冷した銅コイルによる 大型の電磁石でも2T以下である.これ以上の磁場は超伝導コ イルを使った超伝導マグネットで得られるが，液体ヘリウム を使用するためにコストが高く，一般には普及していない. バルク超伝導体は従来の永久磁石と異なった原理で，強い磁 場を簡便に発生できるため，広範な市場応用が期待できる。

筆者らはバルク超伝導体とその磁化挙動の研究を通じて, 超伝導永久磁石の実用化を検討してきた. 1995 年にはこれを 界磁に用いた超伝導モー夕を試作して最大出力 $3.5 \mathrm{~kW}$ を記録 し，バルク超伝導体が実用に近いレベルで機能することを実 証した ${ }^{7,8)}$. 以下にはバルク超伝導体の合成法, パルス磁場に よる着磁法, 冷凍機を組み合わせることによってコンパクト 
な磁場発生装置ができることを示す.

\section{2 超伝導体の磁気的性算}

超伝導体をその $T_{\mathrm{c}}$ 以下に冷却すると電気抵抗が消滅して, 超伝導状態となる。この状態ではジュール発熱が起こらない ため，損失なく電流を流すことができる．電気抵抗の消滅と 並ふ超伝導体の代表的な性質に完全反磁性 (Fig.1) がある. Fig.1(a) は第一種超電導体, (b)は第二種の場合である.超伝導 体に外部から磁場を印加すると，表面に超伝導電流が誘起さ れ，内部への磁場侵入が妨げられる．純金属に代表される第 一種超伝導体では臨界磁場 $H_{c}$ を超えるとこの効果は消失する が(a)，高温超伝導体が属する第二種超伝導体では，下部臨界 磁場 $H_{\mathrm{c} 1}$ を超えると磁化は堿少するが，上部臨界磁場 $H_{\mathrm{c} 2}$ まで 超伝導状態が残る(b). これを湿合状態といい，Fig.2にその様 子を示す．混合状態において，磁場は磁束量子 導体内部に侵入する．磁束量子は超伝導電流によってシール ドされることで全体の超伝導状態は維持される.

この状態で外部から電流を与えると，発生するローレンッ 力によって磁束は運動し，フロー抵抗として損失が生じてし まう．この磁束フローを抑制するため，磁束をピン止めする ことが高い臨界電流密度 の電流を意味する)を得る鍵である.超伝導体ではその組織制 御によって微細な欠宿を導入し，ピン止め点の導入を果たし ている.

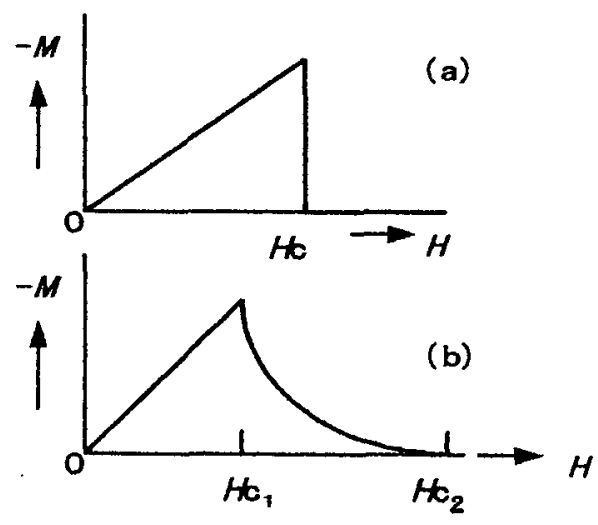

Fig.1 Magnetization of superconductors against the applied field. (a) type I and (b) type II superconductors.

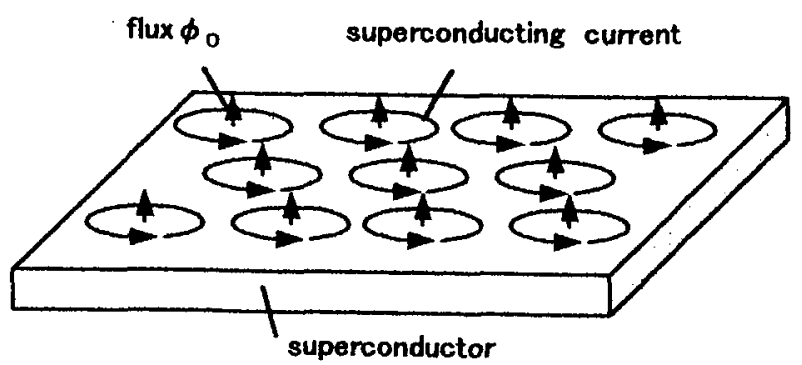

Fig.2 Schematic illustration of mixed state of a type II superconductor.
Fig.3に超伝導状態を貫く磁束量子とピン止め点の様子を示 す9).磁束の中心は常伝導状態になっており, 超伝導状態より も高いエネルギー状態にある。磁束量子に近い寸法の非超伝 導相 (欠宿) があると，磁束量子はこの部分を優先して貫き， $(1 / 2) \mu_{0} H_{\mathrm{c}}{ }^{2} \pi \xi^{2} d$ のエネル゙ーをセーブして磁束は捕捉される.

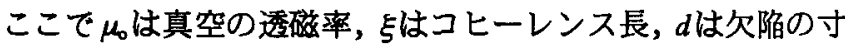
法である．図に示すように，磁束量子にかかるローレンツカ $F_{\mathrm{L}}$ は $F_{\mathrm{L}}=J \times B$ であるからこれに抗するに必要なピン止め力 $F_{\mathrm{P}}=J_{\mathrm{c}} \times B$ が大きいほど，高磁場中で高い $J_{\mathrm{c}}$ をもつ超伝導体と なる.

バルク超伝導体の磁化過程を模式的に Fig.4に示す.バルク 超伝導体を液体公素に清け，磁場をかけると磁場か排除され 反磁性を示す (a). 磁場が強くなると超伝導体内部に磁場が侵 入して磁束量子となり，ピン止め点に捕捉される(b). 外部磁 場を排除しても捕捉された磁束は残り，まるで永久磁石の上 うに振る舞う(c).

\section{3 バルク超伝導体の合成 ${ }^{(0-14)}$}

RE123系 (REは Y，ネオジム Nd またはサマリウムSmを表 わす)のバルク超伝導体は溶融法によって合成される.材料の 組織は超伝導相である母相 $\mathrm{REBa}_{2} \mathrm{Cu}_{3} \mathrm{O}_{7-8}$ (元素の比から 123 相 と呼ふ)に絶緑相の $\mathrm{RE}_{2} \mathrm{BaCuO}_{5}$ (211相, $\mathrm{Nd}$ 系では $\mathrm{RE}_{4} \mathrm{Ba}_{2} \mathrm{Cu}_{2} \mathrm{O}_{10}$, 422 相)が分散したもので，211相がピン止め点として働くこ とから，高い $J_{\mathrm{c}}$ と優秀な捕捉磁場性能が得られる. より微細 な 211 相の分散が高いJ め合成した 123 相と微細な 211 相を混合して熱処理する方法 を考案し，優秀な捕捉磁場性能か得られることを示してきた ${ }^{19}$.

$\mathrm{Y}$ 系では酸素雾囲気で， $\mathrm{Sm}$ 系と $\mathrm{Nd}$ 系では $\mathrm{Sm}, \mathrm{Nd}$ と Baの 元素置换を押さえるために酸素分圧を低下させた雾囲気で行 う.一旦 $1100^{\circ} \mathrm{C}$ に加熱して溶融した試料に，母相より融点の 高い種結晶をその表面に接触させ, 約 $1000^{\circ} \mathrm{C}$ から $1^{\circ} \mathrm{C} / \mathrm{h}$ 以下 の速度で徐冷して大型結晶を合成する.Sm系で合成した試料 の例を Fig.5に示す. 中央に種結晶があり，ここからの優先的 な核生成が起こって, 結晶全体が擬似単結晶となる ${ }^{5,7}$.

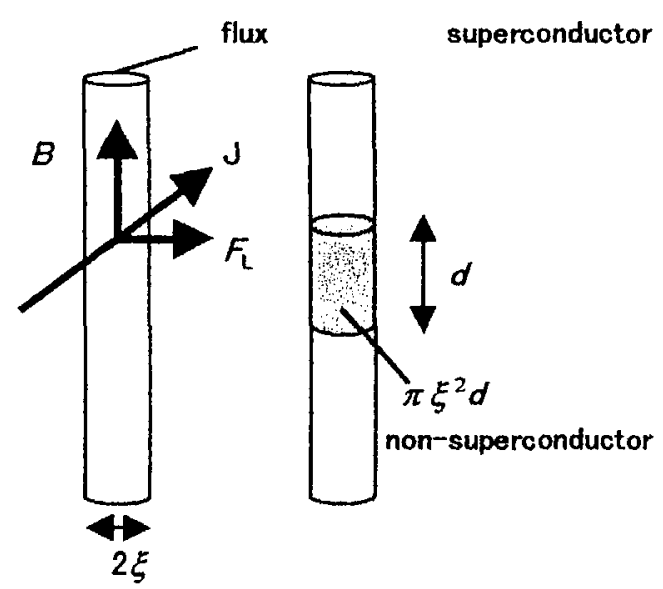

Fig.3 Schematic illustration for flux pinning mechanism due to a non-superconducting particle. 


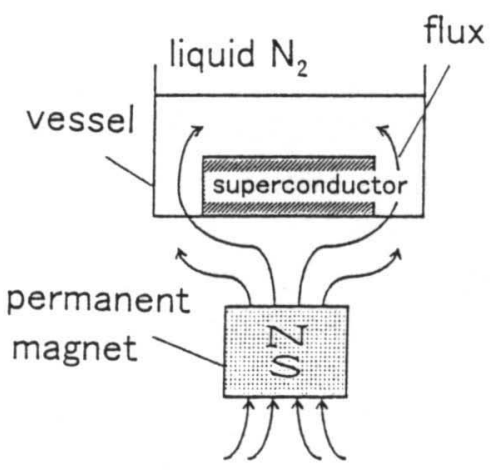

(a)

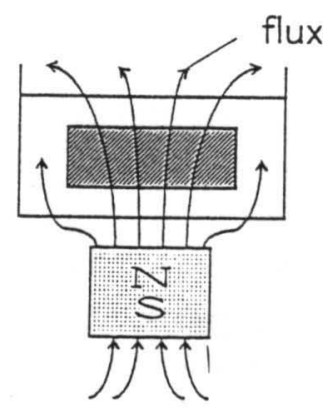

(b)

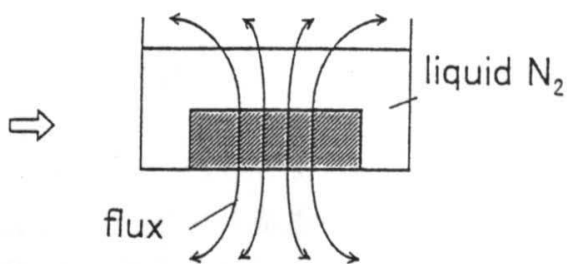

(c)

Fig.4 Magnetic field distribution of a melt-processed bulk superconductor when dc field is applied. (a) Meissner effect, (b) magnetic suspension when field is increased and (c) superconducting permanent magnet when field is removed.

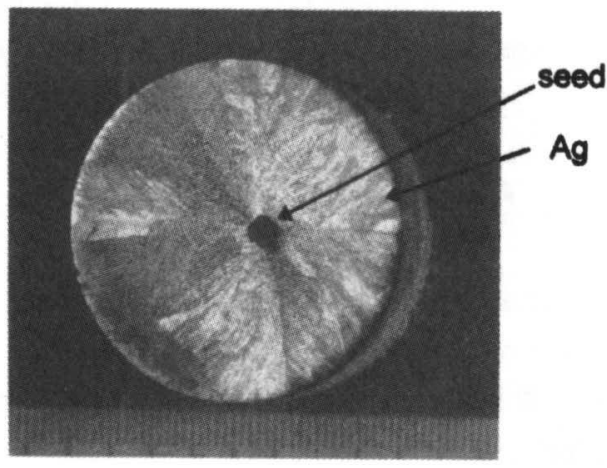

Fig.5 A Melt-textured $\mathrm{Sm}-\mathrm{Ba}-\mathrm{Cu}-\mathrm{O}$ bulk superconductor with the size of $36 \mathrm{~mm}$ in diameter, containing Ag particles. The caxis is aligned perpendicular to the sample surface.

211 相が熱処理時の融液中で粗大化しないよう, Y 系及び $\mathrm{Sm}$ 系の原料には白金 $(\mathrm{Pt})$ 粉末を微量添加する．この方法に よって焼成後に組織中に分散する 211 相を $1 \mu \mathrm{m}$ 程度に抑える ことができ，高い $J_{c}$ を得ることができる. また, $\mathrm{Sm}, \mathrm{Nd}$ 系で は機械的強度の向上を目的に酸化銀粉末を原料に混合する. この結果 $\mathrm{c}$ 軸配向した大型結晶が, $\mathrm{Sm}$ 系で最大 $\phi 36^{12}, \mathrm{Nd}$ 系 では最大 $\phi 30^{13}$ まで合成されている. なお $\mathrm{Sm}, \mathrm{Nd}$ 系試料はそ の試験時にかかる熱応力や電磁力による破損を防ぐため, 金 属製のリングの中に低温用樹脂充填剤で埋め込んで補強する.

バルク超伝導体を磁化したときの捕捉磁場の分布をFig.6(a) に示す. 試料は $\phi 36$ の Sm 系で, 超伝導マグネットの発生する 4Tの静磁場中で 77Kに冷却して着磁した. ホール素子を試料 表面から $0.5 \mathrm{~mm}$ の位置で走査し, 表面に垂直な方向の磁場を 測定した．比較のためにフェライト磁石 $(\phi 22)$ の分布を Fig.6(b) に添える.

䋛軸に磁場をとると,バルク超伝導体に捕捉された磁場は 円錐状に分布し, 試料表面の中央が最大で, 周辺部分ではゼ 口に近い．この分布は永久磁石の示す台形の分布とは対照的 である. 超伝導体の磁場分布は同心円状に流れる超伝導電流 の作る磁場として解析でき, 表面に磁荷が並ぶ永久磁石とは 原理的に異なる。もし試料に亀裂などの欠陥があれば, 超伝 (a)

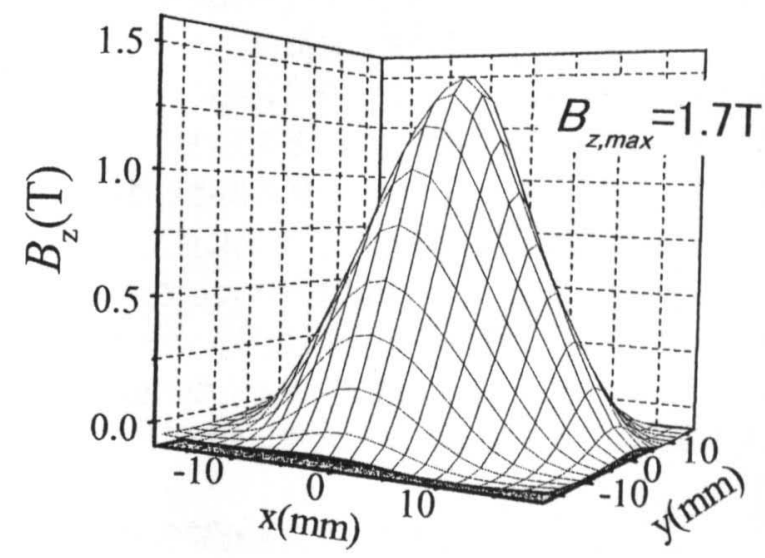

(b)

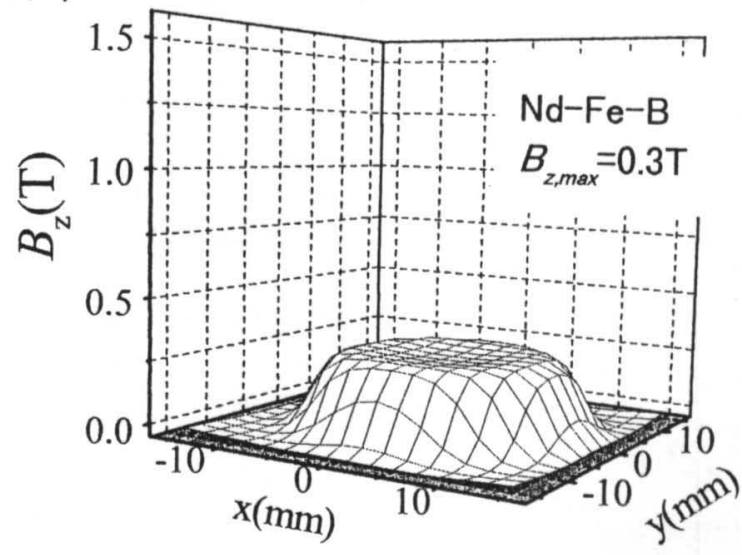

Fig.6 Trapped field distribution of (a) a Sm-Ba-Cu-O bulk sample with the size $36 \mathrm{~mm}$ in diameter magnetized by the static field, and (b) commercially available Nd-Fe-B permanent magnet with the size $22 \mathrm{~mm}$ in diameter. The axial component $B_{\mathrm{z}}$ was measured by scanning a Hall sensor at $0.5 \mathrm{~mm}$ above each sample surface.

導電流の経路が妨げられ, 円錐形状が崩れてしまう. 従って, 図に示す試料のように久陥のない均一な組織が強磁場の捕捉 
には不可欠である．Fig.6に示す77Kでの Sm 系バルクの最大 磁場は試料表面で 1.7T を示す一方, $\mathrm{Nd}$ 系 $\phi 30$ のバルクでは 77Kで 1.0T を示した。これらは従来の Nd-Fe-B系永久磁石の 性能をはるかに超える ${ }^{12,13)}$.

Sm系で合成した $\phi 30$ のバルク超伝導体を最大10Tを発生す る超伝導マグネットの静磁場中で泠却して着磁したときの捕 捉磁場を冷却温度に対して Fig.7に示す. 捕捉磁場は，外部磁 場を取り去った後, 超伝導バルクの表面中心でホール素子を 用いて測定した. 温度の低下とともに捕捉磁場は, $J_{\mathrm{c}}$ の增加を

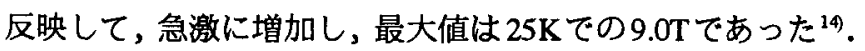
これは 77K の性能の約 5 倍にもなり，冷却が如何に効果的で あるかがわかる. しかもこの磁場性能は従来の永久磁石の約 10倍, 大型電磁石の約 4 倍にも達する強烈なものである.こ のようにバルク超伝導体を $77 \mathrm{~K} よ り$ 低い温度に冷却すること で，従来にない強力な磁石が実現できることがわかる.

試料が磁化するとその磁場に応じた電磁力が，磁化に垂直 な方向にかかる. そのため, さらに低温のデータが久落して いるのは, その最低温度で評価した後, 更に低温で磁化した 際に電磁力に耐えられず破壊したことを意味する。単に $J_{c} た ゙$ けでなく, 電磁力に抗する機械的強度の優劣が最終的な捕捉 磁場性能を決めていることがわかった。図に付記したように， 銀の添加量が多いほどより捕捉磁場が增大しており，試料の 強度が向上していることを示す．銀は結晶の合成中に起こる 亀裂の伝播を㧕制し，均一な結晶を得る上で必要だが，この ように捕捉磁場による電磁力に対して不可欠なことが判明した。

\section{4 バルク超伝尊体のパルス磁化過程 ${ }^{15-20}$}

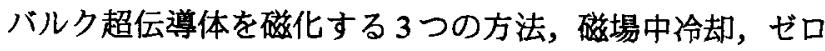
磁場冷却，パルス着磁によって 77K で磁化した試料の捕捉磁 場の総量を Fig. 8 に示す ${ }^{15,17}$. 試料は Y 系 $\phi 35 \mathrm{~mm}$ で, 試料表

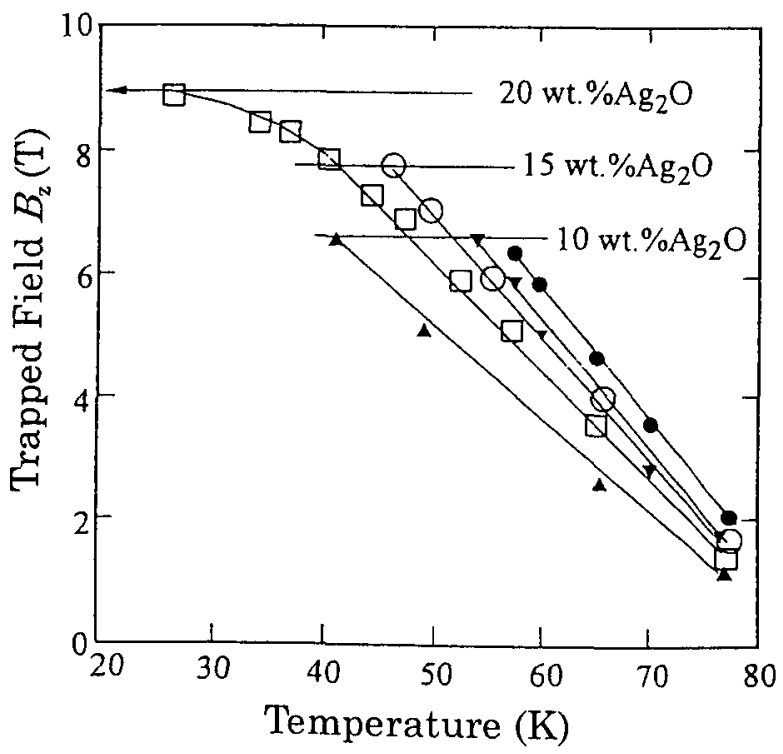

Fig.7 Temperature dependence of the trapped magnetic flux density for several melt-processed samples magnetized by a static field up to $10 \mathrm{~T}$.
面から $0.5 \mathrm{~mm}$ の位置でホールセンサを走查し，軸方向の磁場 成分を検出して積分してある.バルク超伝導体がもつ性能ま で最も有効に磁化する方法は静磁場着磁 (Field cooling)であ り，最も少ない印加磁場で磁化できる。 ゼロ磁場冷却 (Zero field cooling)の場合は磁場のない状態で試料を77Kに冷却し， 準静的に磁場を印加，除去する．磁束はビン止め力に逆らっ て侵入するが, $J_{\mathrm{c}}$ を映した磁場傾斜をもって侵入するため, 中心まで磁化するには静磁場より大きな磁場が必要である。

以上の着磁方法では大型の超伝導マグネットの静磁場を使 う必要があり，応用が著しく制限される。これに対しパルス 着磁では，簡便に着磁できる反面，磁場はさらに侵入しにく く，着磁に大きな磁場が必要となる．Fig.8では約 $2 \mathrm{~T}$ が必要 で，静磁場着磁の数倍である. 磁場がバルク超伝導体に侵入 する時に，その速度に比例して働く粘性力 $F_{\mathrm{v}}$ が余分にかかる ためである．パルス着磁では磁束が試料中を運動するため, 発熱が生じて局所的に $J_{\mathrm{c}}$ を下げ，捕捉磁場性能が下がる. $2 \mathrm{~T}$ 以上の磁場で捕捉磁場が隇少するのはそのためである．77K のY系ではどの方法でもほほ試料の性能まで着磁できるが, $\mathrm{Sm}$ 系や低温では高い $J_{\mathrm{c}}$ を反映して発熱が激しく, 着磁は困難 になる.

パルス磁場の印加中に試料への磁束の侵入をピックアップ コイルで測定した結果が Fig.9である ${ }^{18)}$. 温度は 77Kである. 困の横軸は位置を表し，0がバルク超伝導体表面中央，a が周 辺である. 図の左半分が増磁過程，右が隇磁過程である.

ピン止めによる磁気遮蔽と磁束の運動による粘性力の効果 で試料中に大きな磁場勾配が生じるため, 高い $J_{c}$ をもつ材料 ほどその着磁は困難になる．このため印加磁場の小さい領域 では磁場唚入が妨げられ，殆ど着磁されない(Fig.9(a)). しか し外部磁場が $2.4 \mathrm{~T}$ 以上では, 磁場は試料内部へと雪崩的に侵 入して中心に達し, 試料は完全に着磁される.外部磁場が $2 \mathrm{~T}$ を超えると，それまで下に凸だった分布が上に凸に変化し， 磁場の侵入速度が急激に上がることがかかる。磁束の運動に

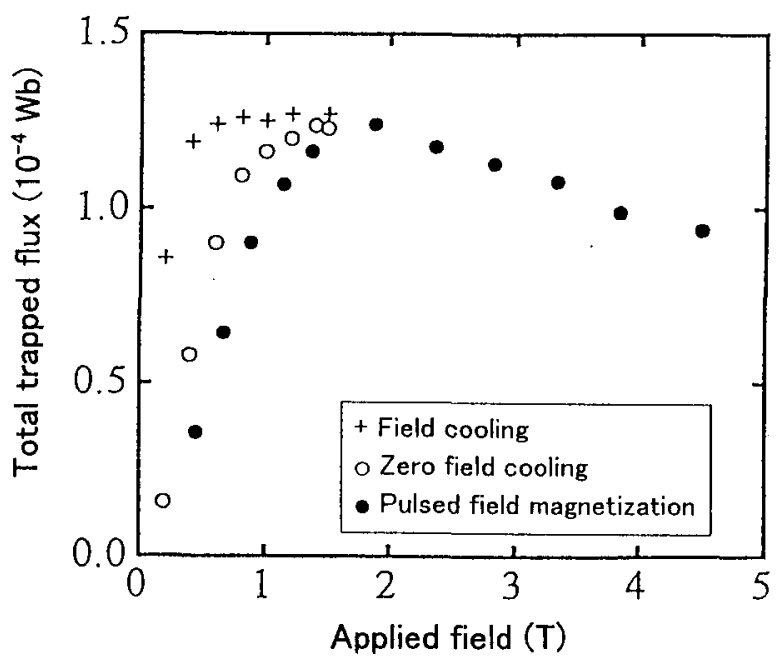

Fig.8 Applied field dependence of the total magnetic flux trapped at $77 \mathrm{~K}$ by pulsed-field magnetization, zero field cooling and field cooling modes. 


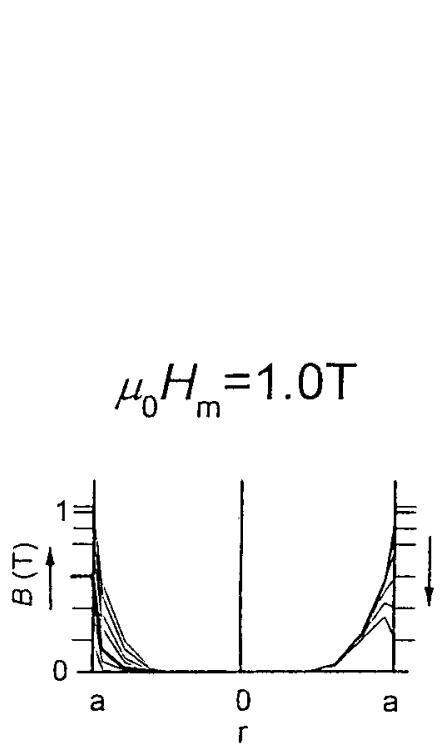

(a)

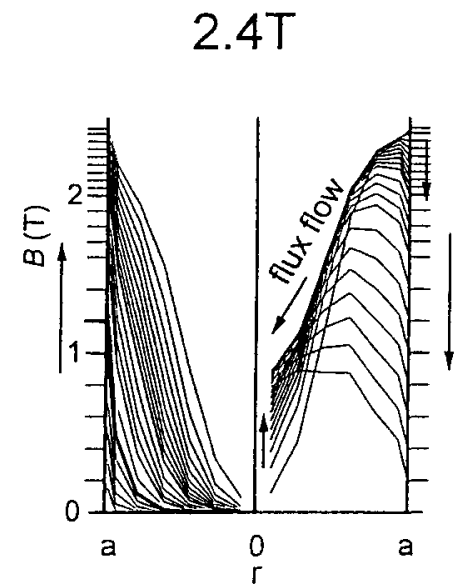

(b)

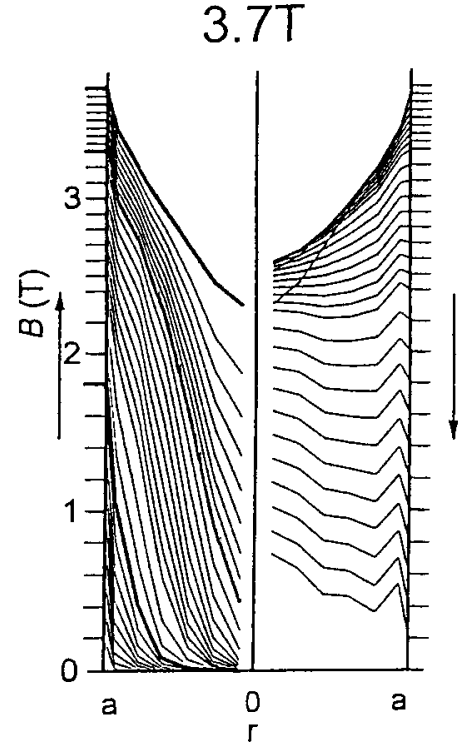

(c)

Fig.9 Change in the flux density distribution in the sample during the pulsed-field magnetization process. The distribution in the ascending and descending stages are shown on the left and right hand sides of each figure, respectively. The maximum applied fields are shown in each figure.

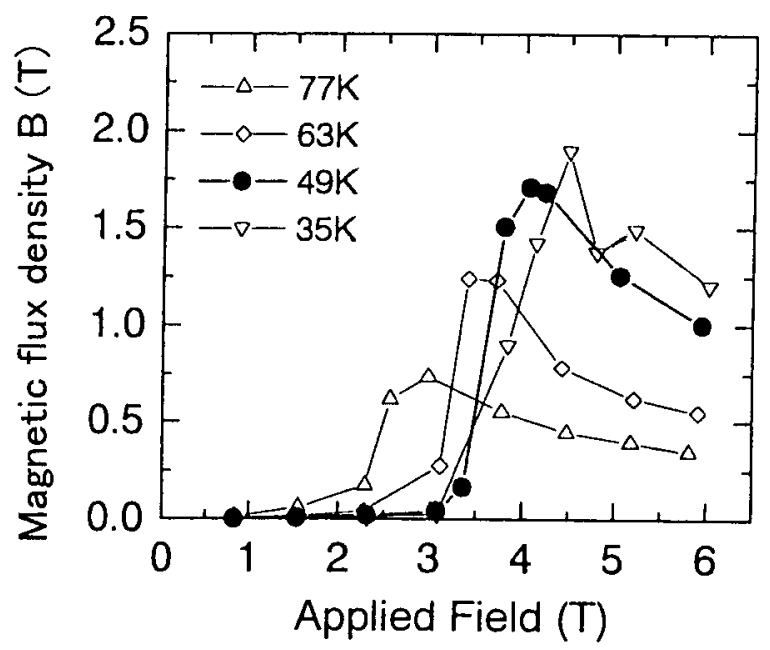

Fig.10 Applied field dependence of the trapped flux density at the center of the sample obtained in the single pulse mode at different temperatures.

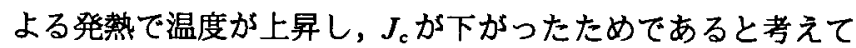
いる. 強いピン止め力のために着磁が困難であると考えられ ていたバルク超伝導体が, 実用的に着磁できることが実験的 に明らかになった ${ }^{11)}$.

Fig.7に示したように，77K以下の温度に冷却すると，バ ク超伝導体の捕捉磁場性能は著しく向上する．そこでギホー ド・マクマホン $(\mathrm{GM})$ 式冷凍機で冷却し，パルス着磁した試料 の捕捉磁場を Fig.10に示す ${ }^{19}$. 試料は $\mathrm{Sm}$ 系 $\phi 36 \mathrm{~mm}$ で，捕捉 磁場の測定は表面中央である．着磁は各温度で 1 回だけ行っ

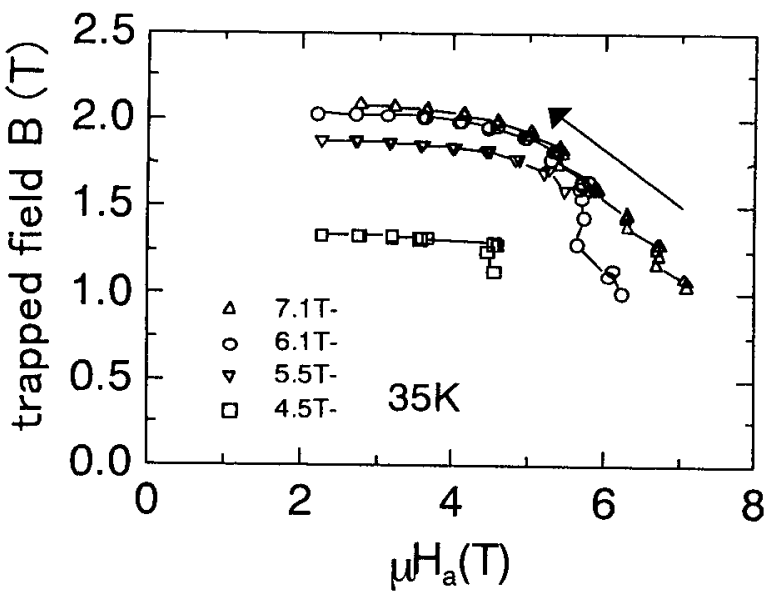

Fig.11 Histories of the trapped flux density at the center of the sample by the IMRA method at $35 \mathrm{~K}$ with various initial applied fields. The arrow indicates the direction of history.

た. $\mathrm{Sm}$ 系はY系よりもJ優れるため, Y系77Kならば試料 中央まで侵入した2Tの印加では，磁場は殆ど侵入しない。し かし 49Kで 4T，35Kで 4.5T 以上の磁場を印加すると，試料は 中心まで着磁される.捕捉磁場性能はFig.8と同様にビークを もち，5Tの印加では発熱のために捕捉磁場は減少する。

試料に侵入する磁束の挙動は，既に捕捉されている磁場の 影翌を受ける. 従って着磁されていない試料へ一回の着磁を する場合と，複数回繰り返す場合では結果が異なる.Fig.11に $35 \mathrm{~K}$ で繰り返しパルス着磁を行った例を示す ${ }^{20)}$. 試料は Y 系 \$36で，ホールセンサは表面中央にある. 最初に着磁して得 られる捕捉磁場はいずれも $1 \mathrm{~T}$ 程度であるが，これを繰り返 
し, しかもより小さな磁場を印加していくと捕捉磁場は, 矢 印に沿って，著しく増加する．しかも最初の磁場が大きいほ ど, 最終的な捕捉磁場は大きい.

強磁場の印加は発熱を生み, $J_{\mathrm{c}}$ は下がって捕捉磁場は低く なる.しかし繰り返して，より低い磁場を印加すると，既に ある磁場の効果で磁束の運動とそれによる発熱が抑制される と推察できる. 反復して着磁する意味からこの方法を IMRA 法 (Iteratively Magnetizing pulsed-field operation with Reducing Amplitude) と呼ふ.この時得られた最大の捕捉磁場は, 7.1Tか ら繰り返し着磁して得た 2.1Tである.

この時の実験の様子を Fig.12 に示す ${ }^{17}$. 装置先端の真空容 器の中に Y 系バルクが装着してあり, GM 式冷凍機で冷却さ れている. パルス着磁されたバルク超伝導体が空間に発散す る磁場に鉄の玉が吸着している.このようにバルク超伝導体 と冷凍機で泠却し, IMRA 法による工夫されたパルス着磁法 を組み合わせると, 強力な磁場を発生する「超伝導永久磁石」 なる磁場発生装置が実現でき，広く一般工業に利用できる磁 場発生機が実現する。

\section{5 超伝導永久磁石の応用 ${ }^{21,22)}$}

超伝導特性の優れた温度域を, 寒剤を使わず冷凍機を用い て実現し,簡便に利用できる磁場発生機として, Fig.13に示す 超伝導永久磁石を試作した ${ }^{21,22}$. Fig.13(a) に外観を，(b)に内 部構成を示した. 装置はバルク超伝導体と冷凍機, 真空ボン プシステムが一体になり，コンパクトに構成してある. 着磁 コイルと着磁電源は表示されていない. パルス着磁後の捕捉
磁場は極めて安定であり, 着磁が済めば，応用分野によって は,これらはもはや必要がない。本体から突き出た上端部が 磁極になり，上方に磁場が発散する。

$\phi 36$ のm系バルク超伝導体がこの磁極中に真空断熱を保っ

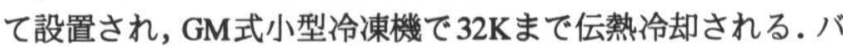
ルク超伝導体表面から容器 (磁極)外面までは $3 \mathrm{~mm}$ ある. 冷 凍機の下方に圧縮機が組み込まれている.これらは交流 $100 \mathrm{~V}$ の電源で駆動し，電力は 800 Wである．熱放射はファンによ る空冷式で泠却水は必要ない。磁極となる真空容器は真空ポ

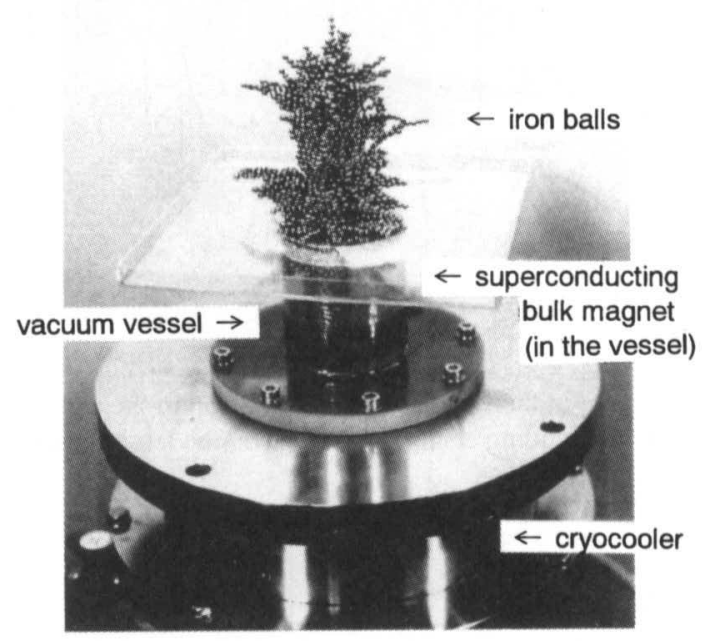

Fig.12 Quasi-permanent magnet system. AY-Ba-Cu-O sample with the size of $35 \mathrm{~mm}$ in diameter is cooled to $30 \mathrm{~K}$ by the GMcryocooler and magnetized by using the IMRA method. A large number of iron balls are attracted by the field of $0.8 \mathrm{~T}$.

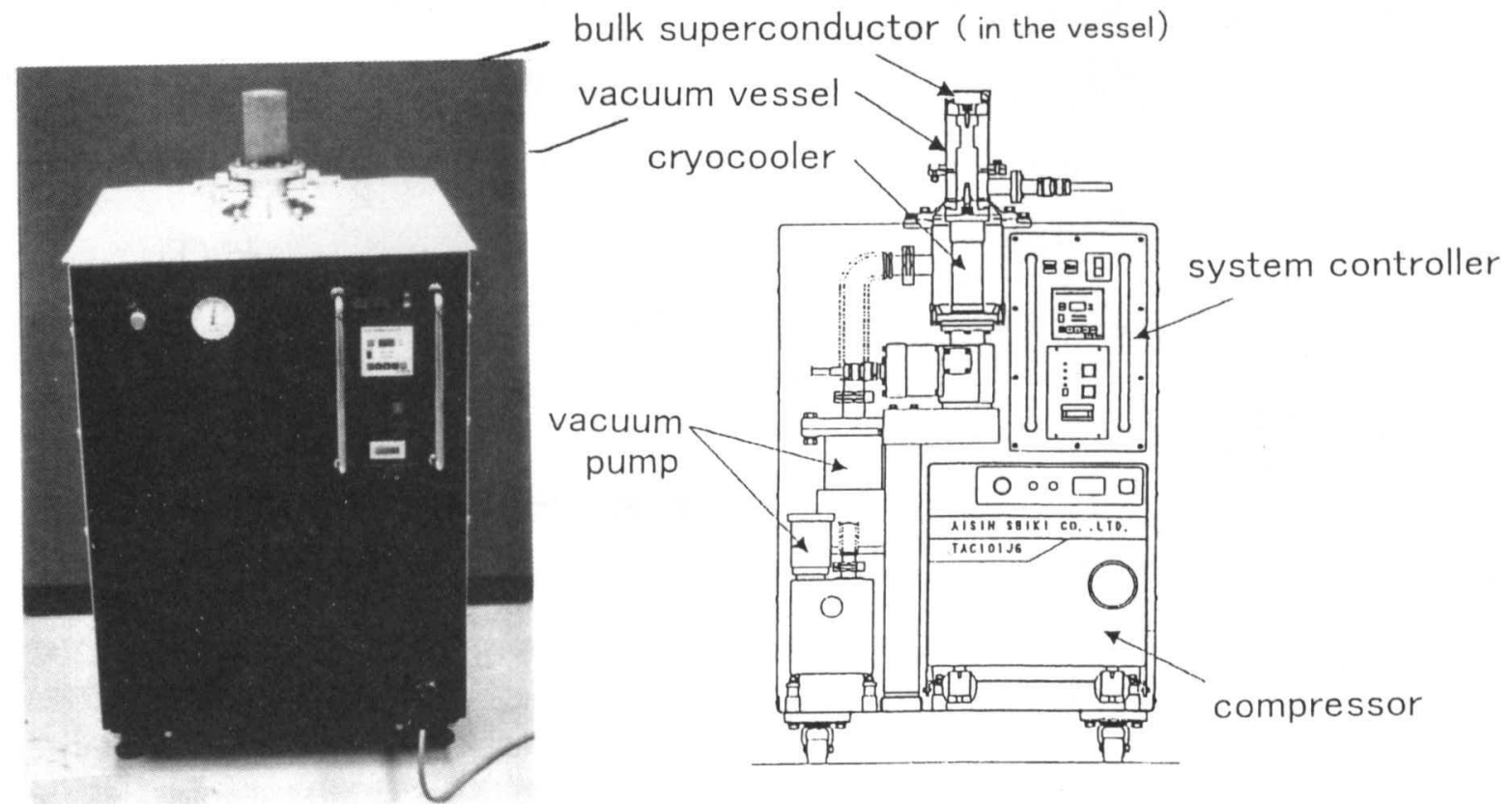

(a)

(b)

Fig.13 A compact superconducting permanent magnet system, (a) the whole assembly and (b) construction. The system consists of a vacuum pump, a GM-cryocooler and a Sm-based bulk superconductor. 
ンプにつながる. 主ボンプはターボ分子ポンプで油回転ポン プにつながり，これらも本体に組み込まれている。真空ポン プと冷凍機は前面のコントローラで制御される．スイッチを 入れるだけで目動運転し，約 2 時間で $32 \mathrm{~K}$ に達する，装置の 主な仕様を Table 1 に示す. 装置全体の所要電力は $1.3 \mathrm{~kW}$ ，重 量は $115 \mathrm{~kg}$ である．現在，装置の性能は急速に向上し，冷凍 機本体を分離した $\mathrm{GM}$ 式冷凍機により，32Kでパルス着磁し て得た性能仕容器表面で $2 \mathrm{~T}$ を記録している.

これまで高温超伝導体は液体窒素温度での応用が強調され てきた.しかし一般工業分野で液体窒素等の寒戍の使用は不 便であり，特殊な技術を要する作業でもある．冷凍機による 冷却の方が簡便で沉用的であることは疑いがない．踟界電流 密度 $J_{\mathrm{c}}$ は温度低下とともに急峻に向上するから，冷凍機の利 用は機器の性能向上に極めて有効である一方，寒郕という煩 雑な作業からも解放される.

超伝導永久磁石は一旦着磁すると磁場の掃引や反転が困難 なため，磁場を変化させて使う応用には向かない．まさに永 久磁石としての使われ方が妥当であろう.バルク超伝導体の もつ急峻な磁場勾配は吸着などへの応用には好適であるし， 強磁場空間が狭いことは外部への磁場の漏れが少ないという 利点にもなる。

従来の永久磁石との性能比較を Table 2 に示す. パルス着磁 した超伝導永久磁石の発生する $2 \mathrm{~T}$ 磁場は, ほほ同じ形状の フェライト磁石の十数倍, 希土類磁石の 4 倍である. 静磁場 によれば最高9Tが捕捉できるから，如何に材料性能に近くま で簡便に着磁できるかが今後の大きな課題である。超伝導永 久磁石は従来の永久磁石や電磁石の磁場を超え，従来の超伝 導マグネットにせまる磁場をコンパクトに発生できる磁場発 生装置である。

\section{6 おわりに}

バルク超伝導体が発生できる磁場は，材料や着磁法の進展

Table 1 Specification of the superconducting permanent magnet system.

\begin{tabular}{|c|c|}
\hline Size & $530 \times 520 \times 760 \mathrm{~mm}$ \\
vacuum vessel & $62 \mathrm{~mm} \mathrm{dia}$. \\
Input power & $1.3 \mathrm{~kW}(\mathrm{AC} 100 \mathrm{~V})$ \\
Weight & $115 \mathrm{~kg}$ \\
Cryocooler & GM cycle \\
Temperature & $32 \mathrm{~K}$ \\
Superconductor & $\mathrm{Sm}-\mathrm{Ba}-\mathrm{Cu}-\mathrm{O}(36 \mathrm{~mm}$ dia. $)$ \\
\hline
\end{tabular}

を受けて今も急速に向上しつつある．超伝導永久磁石によつ て新たな産業への強磁場の応用が進むだろう。例えば，より 小型で高性能なモー夕や発電機が実現するし，医療機器への 応用も期待できる。急峻な磁場勾配を使って，流体からの常 磁性粉の磁気分離が可能となるだろう。

本研究の一部は通産省よりエネルギー使用合理化新規産業 創造技術開発費補助金の交付を受けて実施された。

\section{文献}

1) J.Bednorz and K.Müller: "Possible High $T_{\mathrm{c}}$ Superconductivity in the Ba-La-Cu-O System", Zeitschrift für Physik, 64(1986) 189-193.

2) M.Wu, J.Ashburn, C.Torng, P.Meng, L.Gao, Z.Huang, U.Wang and C.Chu: "Superconductivity at $93 \mathrm{~K}$ in a New Mixed-phase Y-Ba-Cu-O Compound System at Ambient Pressure", Phys. Rev. Lett., 58(1987)908-910.

3) S.Jin, T.Tiefel, R.Sherwood, R.van Dover, M.Davis, G.Kammlott and R.Fastnacht: "Melt-textured growth of polycrystalline $\mathrm{YBa}_{2} \mathrm{Cu}_{3} \mathrm{O}_{7-b}$ with high transport $J_{\mathrm{c}}$ at $77 \mathrm{~K}^{\prime \prime}$, Phys. Rev. B, 37(1988) 7850-7853.

4) M.Murakami, M.Morita, K.Doi and K.Miyamoto: "A New Process with the Promise of High $J_{c}$ in Oxide Superconductors", Jpn. J. Appl. Phys., 28(1989)1189-1194.

5) S.Yoo, N.Sakai, H.Takaichi, T.Higuchi and M.Murakami: "Melt processing for obtaining $\mathrm{NdBa}_{2} \mathrm{Cu}_{3} \mathrm{O}_{y}$ superconductors with high $T_{c}$ and large $J_{c}{ }^{\prime \prime}$, Appl. Phys. Lett., 65(1994)633-636.

6) R.Weinstein, In-Gann Chen, J.Liu and K.Lau: "Permanent magnets composed of high temperature superconductors", J. Appl. Phys., 70(1991)6501-6503.

7) Y.Itoh, Y.Yanagi, M.Yoshikawa, T.Oka, S.Harada, T.Sakakibara, Y.Yamada and U.Mizutani: "High Temperature Superconducting Motor Using Y-Ba-Cu-O Bulk Magnets", Jpn. J. Appl. Phys., 34(1995)5574-5578.

8) 岡徹雄, 伊藤佳孝, 柳 陽介, 吉川雅章, 柇原 務, 原田信 太郎, 山田裕, 水谷宇一郎: " 高温超電導揟似永久磁石と 超電導モータへの応用 ", 日本金属学会誌, 61(1997)931936.

9) M.Murakami: "Melt-Processed High Temperature Superconductors", World Scientific, (1991)192.

10) T.Oka, Y.Itoh, Y.Yanagi, H.Tanaka, S.Takashima, Y.Yamada and U.Mizutani: "Critical current density and mechanical

Table 2 Magnetic field of various permanent magnets.

\begin{tabular}{|c|c|c|c|}
\hline & Ferrite magnet & Rare earth magnet & $\begin{array}{c}\text { Superconducting } \\
\text { permanent magnet }\end{array}$ \\
\hline $\begin{array}{c}\text { Magnetic } \\
\text { field (T) }\end{array}$ & $\begin{array}{c}0.12 \\
\text { (at RT) }\end{array}$ & $\begin{array}{c}0.5 \\
(\text { at } \mathrm{RT})\end{array}$ & $\begin{array}{c}2 \\
(32 \mathrm{~K}, \text { pulse field) }\end{array}$ \\
\hline & $\begin{array}{c}\text { Sr-Ferrite } \\
35 \text { dia. } \times 20\end{array}$ & $\begin{array}{c}\mathrm{Nd}-\mathrm{Fe}-\mathrm{B} \text { system } \\
50 \times 50 \times 30\end{array}$ & $\begin{array}{c}\text { Sm-Ba-Cu-O system } \\
36 \text { dia. } 15 \\
\mathrm{~B}_{2} \text { on the surface }\end{array}$ \\
\hline
\end{tabular}


strength of $\mathrm{YBa}_{2} \mathrm{Cu}_{3} \mathrm{O}_{7-\delta}$ superconducting composites containing $\mathrm{Zr}, \mathrm{Ag}$ and $\mathrm{Y}_{2} \mathrm{BaCuO}_{5}$ dispersions by melt-processing", Physica C, 200(1992)55-64.

11) U.Mizutani, A.Mase, H.Ikuta, Y.Yanagi, M.Yoshikawa, Y.Itoh, T.Oka: "Preparation and Superconducting Properties of c-Axis Oriented $\mathrm{Y}-\mathrm{Ba}-\mathrm{Cu}-\mathrm{O}$ and LRE-Ba-Cu-O (LRE=Nd and Sm) Melt-Textured Bulk Superconductors", Proc. of Int. Workshop on Superconductivity Co-Sponsored by ISTEC and Okinawa Pref. Government, Okinawa, (1998)46-49.

12) H.Ikuta, A.Mase, Y.Yanagi, M.Yoshikawa, Y.Itoh, T.Oka, U.Mizutani: "Melt-processed $\mathrm{Sm}-\mathrm{Ba}-\mathrm{Cu}-\mathrm{O}$ superconductors trapping strong magnetic field", Superconductor Sci. and Technol., 11(1998)1345-1347.

13) 細川哲央, 間瀬淳, 吉川雅章, 伊藤佳孝, 柳陽介, 岡徹雄, 生田博志, 水谷宇一郎: " 銀添加 RE-Ba-Cu-O (RE=Nd, Sm) の作製とその超伝導特性", 第46回応用物理学関係連合講 演会講演予稿集 No.1, 千葉,(1999)254.

14) 生田博志, 岡 徹雄, 水谷宇一郎: " 高温超伝導溶融バルク 材料開発の現状 ", 応用物理, 68(1999)403-406.

15) Y.Itoh and U.Mizutani: "Pulsed Field Magnetization of MeltProcessed Y-Ba-Cu-O Superconducting Bulk Magnet", Jpn. J. Appl. Phys., 35(1996)2114-2125.

16) Y.Itoh, Y.Yanagi and U.Mizutani: "Flux Motion during PulsedField Magnetization in Y-Ba-Cu-O Superconducting Bulk Magnet", J. Appl. Phys., 82(1997)5600-5611.
17) U.Mizutani, T.Oka, Y.Itoh, Y.Yanagi, M.Yoshikawa and H.Ikuta: "Pulsed-Field Magnetization Applied to High- $T_{\mathrm{c}}$ Superconductors", Applied Superconductivity, 6(1998)235-246.

18) A.Terasaki, Y.Yanagi, Y.Itoh, M.Yoshikawa, T.Oka, H.Ikuta and U.Mizutani: "Flux Motion during Pulsed-Field Magnetization in Melt-Processed YBCO", Proc. of 10th Int. Symp. on Superconductivity (ISS'97), Osamura and Hirabayashi, Gifu, 1997, ISTEC, Springer-Verlag, (1998)945-948.

19) Y.Yanagi, Y.Itoh, M.Yoshikawa, T.Oka, A.Mase, T.Hosokawa, H.Ikuta and U.Mizutani: "Flux Dynamics during PulsedField Magnetization in R-Ba-Cu-O ( $=Y, S m)$ Bulk Superconductors", Proc. of 11 th Int. Symp. on Superconductivity (ISS'98), Koshizuka and Tajima, Fukuoka, 1998, ISTEC, Springer-Verlag, (1999)717-720.

20) Y.Yanagi, Y.Itoh, M.Yoshikawa, T.Oka, A.Terasaki, H.Ikuta and U.Mizutani: "Pulsed-Field Magnetization of $\mathrm{Y}-\mathrm{Ba}-\mathrm{Cu}-\mathrm{O}$ Superconducting Bulk Magnet Cooled by Refrigerator", Proc. of 10th Int. Symp. on Superconductivity (ISS'97), Osamura and Hirabayashi, Gifu, 1997, ISTEC, Springer-Verlag, (1998)941944.

21) 水谷宇一郎, 岡 徹雄: "世界最強の磁石の開発", 配管技術, 41(1999)45-50.

22) 生田博志, 岡 徹雄, 水谷宇一郎: " 高温超伝導体の強力擬 似永久磁石としての応用", 日本応用磁気学会誌, 23(1999) 885-892. 